\title{
Lung cancer: is there an association with socioeconomic status in The Netherlands?
}

\author{
A Jeanne $M$ van Loon, $R$ Alexandra Goldbohm, Piet A van den Brandt
}

\begin{abstract}
Study objective - To evaluate if there are differences in lung cancer incidence between socioeconomic groups in the Netherlands and if so, if smoking habits and other lifestyle characteristics could explain these differences.

Design - Prospective cohort study. Baseline measurement included information on socioeconomic status, smoking habits, and other covariates by means of a selfadministered questionnaire. Follow up was established by computerised record linkage to cancer registries and a path-
\end{abstract} ology register.

Setting - Population originating from 204 municipalities in The Netherlands.

Participants - 58279 men aged 55-69 years in September 1986. After $3 \cdot 3$ years of follow up 490 microscopically confirmed incident lung cancer cases were detected.

Main results - An inverse association between lung cancer risk and highest level of education was found, which persisted after adjustment for age, smoking, dietary intake of vitamin $C, \beta$-carotene and retinol (rate ratio (RR) highest/lowest level of education $=0.52,95 \%$ CI $0.33,0.82$, trend p<0.001). Men with a lower white collar profession had a significantly lower relative rate of lung cancer compared with blue collar workers $(R R=0.66,95 \% C I$ $0.47,0.96$ ), but after adjustment for smoking habits this difference was reduced $(\mathbf{R R}=0 \cdot 73,95 \%$ CI $0 \cdot 51,1 \cdot 08)$.

Conclusions - There is an inverse association between highest level of education and lung cancer, which is still apparent after adjustment for age, smoking, dietary intake of vitamin $C$, beta-carotene and retinol. The significantly lower lung cancer risk of lower white collar workers compared with the risk of blue collar workers could be partially explained by smoking habits.

University of Limburg, Department of Epidemiology, POB 616, 6200 MD, Maastricht,

The Netherlands

A J M van Loon

P A van den Brandt

TNO-Toxicology and Nutrition Institute,

Department of Nutrition, Zeist, The Netherlands R A Goldbohm

Correspondence to: A J M van Loon. Accepted for publication March 1994 largely responsible for the difference in lung cancer risk between SES groups. ${ }^{89}$ Smoking has been found to be more prevalent among lower SES groups in most affluent societies. ${ }^{20-12}$ Intake of $\beta$-carotene, vitamin $C$, and retinol is also related to lung cancer risk ${ }^{13-15}$ and subjects of upper SES categories generally eat more fruit and vegetables. ${ }^{1617}$ So, differences in smoking and dietary habits can be partially responsible for differences in lung cancer risk between SES groups. Strangely enough, we could find only one study in which smoking habits were included in the analysis of the relation between SES and lung cancer ${ }^{2}$; surprisingly, this did not change the association between SES and lung cancer. Therefore we examined the association between SES and lung cancer incidence and the influence of various lifestyle factors on it. In particular, we wanted to examine whether differences in smoking habits could explain possible differences in lung cancer incidence between socioeconomic groups in a prospective cohort study on diet, other lifestyle variables and cancer risk.

\section{Methods}

THE COHORT STUDY

In September 1986, a prospective cohort study on various lifestyle variables, sociodemographic indicators, and cancer risk was started in The Netherlands. The cohort included 58279 men, aged 55-69 years at the beginning of the study. Data were collected by means of a self administered questionnaire. A detailed description of the cohort study design has been reported elsewhere. ${ }^{18}$ For data analysis the casecohort approach was used in which cases are derived from the entire cohort, while the person years at risk are estimated from a random sample of 1688 subjects (subcohort). After the baseline exposure measurement, the subcohort was randomly sampled and it has been followed up biennially for vital status information.

Follow up for incident cancer has been established by record linkage with all regional cancer registries in The Netherlands and with a national pathology register (PALGA). The method of record linkage has been described previously. ${ }^{19}$ The analysis is restricted to lung cancer incidence between September 1986 and December 1989. In this period, completeness of follow up was estimated to be $95 \% .{ }^{20}$ After these 3.3 years of follow up, 542 lung cancer cases had been detected. We excluded prevalent cancer cases other than skin cancer, cases with in situ carcinoma, and cases without microscopically confirmed diagnosis. Therefore, 490 incident cases were available for analysis. Prevalent cancer cases other than skin cancer 
Table 1 Distribution of socioeconomic status indicators and other characteristics in lung cancer cases and the subcohort

\begin{tabular}{|c|c|c|}
\hline Characteristic & $\begin{array}{l}\text { Subcohort } \\
\text { No (\%) }\end{array}$ & $\begin{array}{l}\text { Cases } \\
\text { No (\%) }\end{array}$ \\
\hline Total & 1630 & 490 \\
\hline \multicolumn{3}{|l|}{ Age (y): } \\
\hline $55-59$ & $620(38 \cdot 0)$ & $120(24 \cdot 5)$ \\
\hline $60-64$ & $568(34 \cdot 8)$ & $174(35 \cdot 5)$ \\
\hline $65-69$ & $442(27 \cdot 1)$ & $196(40 \cdot 0)$ \\
\hline \multicolumn{3}{|l|}{ Smoking habits: } \\
\hline Never & $159(9 \cdot 8)$ & $7(1 \cdot 4)$ \\
\hline Ex-smoker & $771(47 \cdot 4)$ & $146(30 \cdot 2)$ \\
\hline Current & $697(42 \cdot 8)$ & $332(68 \cdot 4)$ \\
\hline \multicolumn{3}{|c|}{ Highest level of education: } \\
\hline Primary school & $458(28 \cdot 4)$ & $166(34 \cdot 6)$ \\
\hline Lower vocational & $338(20.9)$ & $125(26 \cdot 0)$ \\
\hline Junior high school & $420(26 \cdot 0)$ & $111(23 \cdot 1)$ \\
\hline Senior high school & $123(7 \cdot 6)$ & $31(6 \cdot 5)$ \\
\hline $\begin{array}{l}\text { Higher vocational/ } \\
\text { university }\end{array}$ & $275(17 \cdot 0)$ & $47(9 \cdot 8)$ \\
\hline \multicolumn{3}{|c|}{ EGP score: last profession: } \\
\hline Blue collar & $563(38 \cdot 8)$ & $186(44 \cdot 2)$ \\
\hline Lower white collar & $206(14 \cdot 2)$ & $47(11 \cdot 2)$ \\
\hline Upper white collar & $436(30 \cdot 0)$ & $118(28 \cdot 0)$ \\
\hline Other & $247(17 \cdot 0)$ & $70(16 \cdot 6)$ \\
\hline
\end{tabular}

were also excluded from the subcohort, with the result that 1630 remained in this group.

\section{SOCIOECONOMIC STATUS}

SES was measured by means of highest attained level of education and occupational history, two of the recommended measures for SES. ${ }^{21}$ Educational level was classified as primary school, lower vocational school (for example, technical school, domestic science school), junior high school, senior high school, higher vocational school, university and other education. Information about occupational history was coded according to a coding system of the Central Bureau of Statistics (CBS) frequently used in The Netherlands. ${ }^{22}$ For the present analysis, these CBS codes were aggregated according to occupational group and required training (EGP). The EGP coding scheme is a reconstruction of the scheme developed by Erikson, Goldthorpe, and Portocarero, ${ }^{2324}$ which is still comparable with the original list. ${ }^{25}$

\section{LIFESTYLE CHARACTERISTICS}

Other factors relevant to the association between SES and lung cancer risk that were measured are lifetime history of smoking habits and the intake of $\beta$-carotene, vitamin $C$, and retinol. Information on smoking habits comprised smoking status (never, ex-smoker, or current), age at starting smoking, age at stopping smoking when applicable, total years of

Table 2 Association between possible confounders and socioeconomic status indicators in the subcohort

\begin{tabular}{|c|c|c|c|c|c|c|}
\hline \multirow[t]{2}{*}{ Characteristic } & \multicolumn{3}{|c|}{ Highest level of education* } & \multicolumn{3}{|c|}{ EGP score } \\
\hline & Low & Medium & High & $\begin{array}{l}\text { Blue } \\
\text { collar }\end{array}$ & $\begin{array}{l}\text { White } \\
\text { collar }\end{array}$ & Other \\
\hline $\begin{array}{l}\text { Age (mean yrs) } \\
\text { Current smokers (\%) } \\
\text { Ex-smokers (\%) } \\
\text { Pack-years† (mean) } \\
\beta \text {-carotene (mean, mg eq vit A) } \\
\text { Vitamin C (mean, mg) } \\
\text { Retinol (mean, mg eq vit A) }\end{array}$ & $\begin{array}{l}61 \cdot 9 \\
50 \cdot 7 \\
40 \cdot 2 \\
23 \cdot 6 \\
0 \cdot 40 \\
92 \cdot 4 \\
0 \cdot 59\end{array}$ & $\begin{array}{c}61 \cdot 3 \\
38 \cdot 9 \\
51 \cdot 2 \\
25 \cdot 1 \\
0 \cdot 40 \\
100 \cdot 0 \\
0 \cdot 61\end{array}$ & $\begin{array}{c}61 \cdot 1 \\
40 \cdot 7 \\
49 \cdot 0 \\
24 \cdot 1 \\
0 \cdot 41 \\
101 \cdot 0 \\
0 \cdot 64\end{array}$ & $\begin{array}{c}61 \cdot 3 \\
46 \cdot 2 \\
46 \cdot 5 \\
23 \cdot 0 \\
0 \cdot 41 \\
97 \cdot 1 \\
0 \cdot 60\end{array}$ & $\begin{array}{c}61 \cdot 1 \\
39 \cdot 4 \\
50 \cdot 3 \\
22 \cdot 2 \\
0 \cdot 41 \\
102 \cdot 0 \\
0 \cdot 61\end{array}$ & $\begin{array}{l}61 \cdot 8 \\
40 \cdot 1 \\
47 \cdot 8 \\
20 \cdot 9 \\
0 \cdot 42 \\
96 \cdot 4 \\
0 \cdot 66\end{array}$ \\
\hline
\end{tabular}

* Highest level of education: low = primary school; medium = lower vocational or junior high school; high = senior high school, higher vocational or university

t Only for current and ex-smokers smoking, and the amount of cigarettes, cigars and/or pipes smoked per day. For the multivariate analyses, pack-years for current and ex-smokers were computed. The usual consumption of food and beverages during the year preceding the start of the study was assessed at baseline with an 150 item, semiquantitative food frequency questionnaire. This questionnaire has been validated against a nine day diet record ${ }^{26}$ Mean individual nutrient intakes per day are computed using the Dutch food table of $1986 .^{27}$

\section{DATA ANALYSIS}

The distribution of SES indicators and potential confounders known to be associated with SES and lung cancer (particularly smoking habits) were compared between the case and subcohort group. Educational level was aggregated into five categories: primary school, lower vocational school, junior high school, senior high school, and higher vocational school or university. The occupation based SES indicator (EGP score) was derived from the last job that was held, and was divided into four categories: upper white collar jobs (professionals), lower white collar jobs (administrators and non-manual employees), blue collar jobs (lower grade technicians, semi- and unskilled manual workers), and other (farmers and self employed people). The associations between SES and covariates were also studied in the subcohort by comparing mean values of age; pack-years of cigarette smoking; and intake of $\beta$-carotene, vitamin $C$, and retinol in relevant SES categories. To study the association between SES and lung cancer risk and the role of smoking habits with respect to that association, data were analysed according to the case-cohort approach. ${ }^{2028}$ Mantel-Haenszel rate ratios of lung cancer were determined for each of the SES indicators, stratified for age and smoking habits. In the multivariate case-cohort analyses, using the GLIM statistical package, ${ }^{29}$ rate ratios and $95 \%$ confidence intervals of lung cancer were computed for the SES indicators, after adjustment for age, smoking (pack-years of current smokers and past smokers), and intake of $\beta$-carotene, vitamin $C$, and retinol. All these covariates were entered into the model as continuous variables.

\section{Results}

The distribution of SES indicators and covariates in the case and the subcohort group is presented in table 1 . On average, cases were older than members of the subcohort (mean age for cases is 62.9 years and for subcohort members 61.4 years) and current smoking was more prevalent in the case groups. Cases had a lower educational level and were more often employed in blue collar occupations than members of the subcohort.

The comparison of the distribution of never, ex-smokers, and current smokers in the three SES indicators and the mean values of age, pack-years of cigarette smoking, and intake of $\beta$-carotene, vitamin $C$, and retinol between 
Table 3 Mantel-Haenszel rate ratios for lung cancer according to two different socioeconomic status (SES) indicators

\begin{tabular}{|c|c|c|c|c|c|c|}
\hline \multirow[t]{2}{*}{ SES indicator } & \multicolumn{4}{|c|}{ Adjusted for age } & \multicolumn{2}{|c|}{ Adjusted for age and smoking } \\
\hline & $\begin{array}{l}\text { No of } \\
\text { cases in } \\
\text { cohort }\end{array}$ & $\begin{array}{l}\text { Person } \\
\text { years in } \\
\text { subcohort }\end{array}$ & $R R_{M H}(95 \% C I)$ & $\begin{array}{l}\text { Test for trend } \\
\chi^{2}(p \text { value })\end{array}$ & $R R_{M H}(95 \% C I)$ & $\begin{array}{l}\text { Test for trend } \\
\chi^{2}(p \text { value })\end{array}$ \\
\hline \multicolumn{7}{|c|}{ Highest level of education: } \\
\hline Primary school & 166 & 1457 & $1^{*}$ & & $1^{*}$ & \\
\hline Lower vocational & 125 & 1098 & $1.07(0.81,1.42)$ & $19 \cdot 7$ & $1.18(0.89,1.58)$ & 11.9 \\
\hline Junior high school & 111 & 1344 & $0.76(0.57,1.00)$ & $(<0.001)$ & $0.86(0.65,1.15)$ & $(<0.001)$ \\
\hline Senior high school & 31 & 397 & $0.69(0.44,1.06)$ & & $0.75(0.48,1.18)$ & \\
\hline $\begin{array}{l}\text { Higher vocational/ } \\
\text { university }\end{array}$ & 47 & 882 & $0.50(0.35,0.73)$ & & $0.57(0.39,0.82)$ & \\
\hline \multicolumn{7}{|c|}{ EGP score last profession: } \\
\hline Blue collar & 186 & 1804 & $1^{*}$ & & $1^{*}$ & \\
\hline Lower white collar & 47 & 666 & $0.66(0.47,0.96)$ & $1.97(0 \cdot 16)$ & $0.73(0.51,1.08)$ & $0.41(0.52)$ \\
\hline Upper white collar & 118 & 1402 & $0.84(0.64,1.10)$ & & $0.94(0.71,1.24)$ & \\
\hline Othert & 70 & 798 & $0.82(0.60,1 \cdot 13)$ & & $0.90(0.64,1.25)$ & \\
\hline
\end{tabular}

* Reference category

† Excluded from test for trend

Table 4 Rate ratio for lung cancer according to two different socioeconomic status (SES) indicators in multivariate analysis*

\begin{tabular}{|c|c|c|c|}
\hline SES indicator & $R R t$ & $95 \% C I$ & $\begin{array}{l}\text { Test for trend } \\
\chi^{2}(p \text { value })\end{array}$ \\
\hline \multicolumn{4}{|l|}{ Highest level of education: } \\
\hline Primary school & $1 \mp$ & & \\
\hline Lower vocational & $1 \cdot 36$ & $0.97-1.91$ & $14.90(<0.001)$ \\
\hline Junior high school & 0.95 & $0 \cdot 68-1 \cdot 33$ & \\
\hline Senior high school & $0 \cdot 89$ & $0.53-1.49$ & \\
\hline Higher voc/university & 0.52 & $0.33-0.82$ & \\
\hline \multicolumn{4}{|l|}{ EGP score, last profession: } \\
\hline Blue collar & $1 \neq$ & & \\
\hline Lower white collar & 0.69 & $0 \cdot 49-1 \cdot 20$ & $0.85(0.36)$ \\
\hline Upper white collar & 0.90 & $0 \cdot 66-1 \cdot 23$ & \\
\hline Other\$ & 0.78 & $0 \cdot 53-1 \cdot 14$ & \\
\hline
\end{tabular}

* Only respondents with complete dietary data

+ Adjusted for age, smoking behaviour (pack-years), $\beta$ carotene, vitamin $\mathrm{C}$, and retino

$¥$ Reference category

$\oint$ Excluded from test for trend trend $\mathrm{p}<0.001)$. There was still an inverse association between lung cancer risk and educational level after adjustment for age and smoking habits ( $R R$ highest/lowest education = $0.57,95 \%$ CI $0.39,0.82$, trend $\mathrm{p}<0.001$ ), although the differences between the SES categories were somewhat diminished. After adjustment for age, men with a lower white collar profession had a significantly lower lung cancer rate than blue collar workers $(\mathrm{RR}=0.66,95 \%$ CI $0.47,0.96$ ), while upper white collar workers had a non-significantly lower rate $(R R=0 \cdot 84$, $95 \%$ CI $0 \cdot 64,1 \cdot 10)$. Additional adjustment for smoking led to a non-significantly lower lung cancer rate for both upper and lower white collar workers, compared with blue collar workers.

Table 4 shows the results of the multivariate analyses where adjustment is made for age, pack-years of ex-smoking and current smoking, and intake of $\beta$-carotene, vitamin $C$, and retinol. These results are comparable with the results of the stratified analysis. There was still a significant inverse association between level of education and lung cancer risk (trend $\mathrm{p}<0.001$ ). The rate ratio for men with a higher vocational training or university versus primary school education was $0.52(95 \%$ CI $0.33,0.82)$, but those with a lower vocational training had a higher risk for lung cancer than men with primary schooling ( $R R=1 \cdot 36,95 \%$ CI 0.97 , 1.91). After adjustment for age, smoking, and the intake of $\beta$-carotene, vitamin $C$, and retinol, upper white collar workers still had a nonsignificantly lower risk for lung cancer compared with blue collar workers $(R R=0 \cdot 90,95 \%$ CI $0.66,1 \cdot 23)$. The lung cancer rate of lower white collar workers was lower than the rate for blue collar or upper white collar workers.

Table 5 Rate ratios for lung cancer according to highest level of education, by category of smoking* in multivariate analysist

\begin{tabular}{|c|c|c|c|c|c|c|}
\hline \multirow[t]{2}{*}{ Smoking } & \multicolumn{5}{|c|}{ Highest level of education } & \multirow[b]{2}{*}{$\begin{array}{l}\text { Test for trend } \\
\chi^{2}(p \text { value })\end{array}$} \\
\hline & $\begin{array}{l}\text { Primary } \\
\text { school }\end{array}$ & $\begin{array}{l}\text { Lower } \\
\text { vocational }\end{array}$ & $\begin{array}{l}\text { funior high } \\
\text { school }\end{array}$ & $\begin{array}{l}\text { Senior high } \\
\text { school }\end{array}$ & $\begin{array}{l}\text { Higher vocational } \\
\text { university }\end{array}$ & \\
\hline $\begin{array}{l}\text { Ex-smoker } \\
(95 \% \mathrm{CI}) \\
\text { Current } \\
(95 \% \mathrm{CI}) \\
\text { Total } \\
(95 \% \mathrm{CI})\end{array}$ & $\begin{array}{l}1 \neq \\
1 \neq\end{array}$ & $\begin{array}{l}1 \cdot 21 \\
(0 \cdot 71,2 \cdot 07) \\
1 \cdot 59 \\
(0 \cdot 99,2 \cdot 54) \\
1 \cdot 36 \\
(0 \cdot 97,1 \cdot 91)\end{array}$ & $\begin{array}{l}0.86 \\
(0.51,1.44) \\
1.07 \\
(0.68,1.69) \\
0.95 \\
(0.68,1.33)\end{array}$ & $\begin{array}{l}1 \cdot 37 \\
(0 \cdot 67,2 \cdot 81) \\
0 \cdot 79 \\
(0 \cdot 37,1 \cdot 67) \\
0 \cdot 89 \\
(0 \cdot 53,1 \cdot 49)\end{array}$ & $\begin{array}{l}0.84 \\
(0.46,1.54) \\
0.51 \\
(0.28,0.95) \\
0.52 \\
(0.33,0.82)\end{array}$ & $\begin{array}{c}0.49(0.49) \\
7.65(0.006) \\
14.9(<0.001)\end{array}$ \\
\hline
\end{tabular}

* Only respondents with complete dietary data

$\dagger$ Adjusted for age, pack-years of smoking and intake of $\beta$-carotene, retinol, vitamin $C$

$\ddagger$ Reference category 
We have also conducted multivariate analyses including age of starting smoking as an additional covariable. This did not change the association between lung cancer and the SES indicators.

We have studied the association between highest level of education and lung cancer risk more extensively by conducting the multivariate analysis in the different smoking categories (table 5). Unfortunately it was not possible to carry out the analyses for nonsmokers, since there were only seven cases in the non-smoking group. The inverse association between educational level and lung cancer risk seems restricted to current smokers (RR highest/lowest education $=51,95 \%$ CI $0.28,0.95$, trend $\mathrm{p}=0.006$ ). For ex-smokers the rate ratio of lung cancer was still below one for men with higher vocational training or university, but the rate ratios in the different categories and the trend test were not significant (RR highest/lowest $=0.84,95 \%$ CI $0 \cdot 46,1 \cdot 54$, trend $\mathrm{p}=0.49$ ).

\section{Discussion}

We have found a significant inverse association between educational level and lung cancer risk. This association persisted but became somewhat weaker after adjustment for smoking behaviour and dietary intake of vitamins. The associations between lung cancer risk and the occupation based SES indicator is less strong. Men with a lower white collar occupation had a significantly lower relative risk for lung cancer than blue collar workers but after additional adjustment for smoking habits this difference was reduced.

The cohort study has been performed in a large sample of the general population aged 55-69 years at baseline, resulting in a relatively large number of incident cases. The follow up of person years was $100 \%$ complete and the completeness of cancer follow up was also very high, indicating that selection bias because of loss to follow up is unlikely. Although known risk factors for lung cancer were carefully measured and controlled for in the multivariate analyses, residual confounding by smoking habits can still exist. Adjustment for smoking was made by means of pack-years of past and current smokers. This kind of control takes both duration and amount into account. We have also additionally adjusted for the age of starting smoking, with the same results. To exclude the confounding effect of smoking on the association between SES and lung cancer as completely as possible, we have studied the association between SES and lung cancer in the different smoking categories. Due to the number of cases this was only possible for exsmokers and current smokers. We expect that after a longer follow up period the number of cases also allows analyses in the non-smoking group and in subgroups of current smokers.

Another fact that could have had an influence on the results is misclassification. SES is operationalised as highest level of education and EGP score (functional level), based on the last occupation. Highest level of education is a characteristic that is easily obtainable and recordable. It applies to every adult individual and in individuals it is stable over time. This stability has also negative implications for the suitability of level of education as an SES indicator, while it can mask important changes in individual circumstances after education is finished ${ }^{30}$; therefore highest level of education is probably a less relevant SES indicator for the older generation. ${ }^{31}$ On the other hand, at an older age the level of education still has an association with level of knowledge, ${ }^{32}$ which is related to lifestyle. The EGP score reflects the more recent situation, but this occupation based SES indicator leads to the problem of how to classify people without formal occupation. Because we used occupation as an indicator of SES, it seems reasonable to take the last occupation instead of the occupation performed the longest. Also for pensioners - a relatively large part of the study population the last occupation is used. This may not be an accurate reflection of the person's occupational status, however, as elderly people may take less demanding jobs before retirement. ${ }^{21}$ In some studies an aggregated summary measure is used as an SES indicator. We have chosen to use two separate SES indicators, since an aggregated measure focusses on the commonality shared by the separate measures, ${ }^{21}$ while education and occupation are not redundant measures of SES. ${ }^{33}$

These results are partly comparable with other studies on SES and lung cancer incidence. All studies on SES and lung cancer found an inverse (age-adjusted) association ${ }^{1-6}$ independent of study design, both for educational level and occupation, with relative risks of the highest versus the lowest categories varying from 0.4 to 0.9 . Adjustment for smoking was made in only two studies on SES and lung cancer risk. In a cross-sectional study on SES and lung cancer ${ }^{2}$ the OR for lung cancer of the highest versus lowest education changed from 0.62 to 0.68 after adjustment for smoking. This is comparable with our findings which showed only a modest effect of adjustment for smoking. In a cohort study in Denmark, ${ }^{34}$ a significant inverse association was recently reported between social class (based on level of education and job profile) and lung cancer (RR highest/ lowest $=0 \cdot 27,95 \%$ CI $0 \cdot 1,0 \cdot 5$ ), which became somewhat weaker but was still apparent after adjustment for smoking ( $R R=0.34,95 \% C I$ $0 \cdot 2,0 \cdot 7)$. In our cohort study there is a strong association between smoking and lung cancer, but in the study population only $10 \%$ of the men have never smoked and this percentage was not substantially different between SES categories. Therefore differences between SES categories were probably too small to find an important effect of smoking on the association between SES and lung cancer incidence.

Another risk factor for lung cancer associated with SES is occupational exposure to carcinogens. ${ }^{3536}$ Occcupational categories with a higher risk of lung cancer are metal production and processing workers, road construction workers, chemical workers, ${ }^{37}$ textile workers, cooks, ship and dockyard workers, 
and wood workers. ${ }^{38}$ In our cohort representing the general population, the proportion of these occupations is rather small. Therefore, the power to study the association is still small with 3.3 years of follow up. In future analyses with longer follow up and more cases we will investigate this subject specifically.

We have studied the association between level of education and lung cancer risk in different smoking categories. These analyses show that the significant inverse association between education and lung cancer is restricted to current smokers, while there was no association found between education and lung cancer in the ex-smoking group. A cohort study in Denmark, with 17 years of follow up, showed a significant inverse association between SES and lung cancer risk among current smokers. ${ }^{34}$ The number of cases was too small to get insight in the association between SES and lung cancer risk among ex-smokers and nonsmokers.

In conclusion, we found a significant inverse association between lung cancer risk and highest level of education. This association was still apparent after adjustment for age, smoking, dietary intake of vitamin $\mathrm{C}, \beta$-carotene, and retinol. Men with a lower white collar profession had a significantly lower rate ratio of lung cancer compared with blue collar workers, but after adjustment for smoking habits this difference was reduced. Future analyses after a longer follow up will give more information on occupational exposure to carcinogens.

We thank the participants in this study, the regional cancer registries (IKA, IKL, IKMN, IKN, IKO, IKR, IKST, IKW, IKZ), PALGA for providing incidence data; $E$ Dorant, $S$ van de Crommert, H Brants, P Florax, J Nelissen, and W van Dijk for assistance in the cohort study and $S$ van den Heuvel from the TNO-NIPG institute for coding the questions about occupation.

This work was supported financially by the Dutch Ministry of Welfare, Public Health and Cultural Affairs and by the Dutch Cancer Society.

1 Baquet CR, Horm JW, Gibbs T, Greenwald P. Socioeconomic factors and cancer incidence among blacks and whites. $\mathcal{F}$ Natl Cancer Inst 1991;83:551-7.

2 Williams RR, Horm JW. Association of cancer sites with tobacco and alcohol consumption and socioeconomic status of patients: interview study from the third national tus of patients: interview study from the third nation

3 Wynder EL, Stellman SD. Comparative epidemiology of tobacco-related cancers. Cancer Res 1977;37:4608-22.

4 Teppo L. Cancer incidence by living area, social class and occupation. Scand $\mathcal{f}$ Work Environ Health 1984;10:361-6.

5 Vågerö D, Persson G. Occurrence of cancer in socioeconomic groups in Sweden. Scand $\mathcal{F}$ Soc Med 1986;14 151-60.

6 Leon DA. Longitudinal study. Social distribution of cancer 1971-1975 London: HMSO, 1988. OPCS Series LS No 3.

7 Slater C, Carlton B. Behavior, lifestyle, and socioeconomic variables as determinants of health status: implications for
health policy development. Am f Prev Med 1985;1:25-33.

8 Pearce NE, Howard JK Occupation, social class and male cancer mortality in New Zealand, 1974-78. Int $\mathcal{f}$ Epidemiol
$1986 ; 15: 456-62$.

9 Levi F, Negri E, La Vecchia CL, Cong-Te V. Socio-economic groups and cancer: Risk at death in the Swiss canton of groups and cancer: Risk at death in the
Vaud. Int $\mathcal{F}$ Epidemiol 1988;17:711-17.

10 Sterling TD, Weinkam JJ. Smoking patterns by occupation, industry, sex, and race. Arch Environ Health 1978;37: 313-17

11 Rosén M, Hanning M, Wall S. Changing smoking habits in Sweden: towards better health, but not for all. Int $\mathcal{f}$ Epidemiol 1990;19:316-22.

12 De Vries H, Hoekstra I, Dijkstra M, Kok GJ. Opvattingen van jongeren over roken: sociaal-economische statusverschillen. Tijdschr Soc Gezondheids 1992;70:303-9.

13 Kvale G, Bielke E, Gart JJ. Dietary habits and lung cancer risk. Inj f Cancer 1983;31:397-405.

14 Graham S. Epidemiology of retinoids and cancer. 7 Nat Cancer Inst 1984;73:1423-8.

15 Byers TE, Graham S, Haughey BP, Marshall JR, Swanson $M$. Diet and lung cancer risk: Findings from the western M. Diet and lung cancer risk: Findings from the western

16 Hulshof KFAM, Löwik MRH, Kok FJ, Wedel M, Kistemaker C, Brants HAM. Invloed van sociaalKistemaker C, Brants HAM. Invloed van sociaaleconomische status op voeding en andere leefstijlfactoren. In: Mackenbach JP, ed. Sociaal-economische gezon

17 Block G, Sorenson A. Vitamin C intake and dietary sources by demographic characteristics. Nutr Cancer 1987;10:5365 .

18 Van den Brandt PA, Goldbohm RA, Van 't Veer P, Volovics A, Hermus RJJ, Sturmans F. A large-scale prospective cohort study on diet and cancer in the Netherlands. 7 Clin Epidemiol 1990;43:285-95.

19 Van den Brandt PA, Schouten LJ, Goldbohm RA, Dorant E, Hunen PMH. Development of a record linkage protocol for use in the Dutch cancer registry for epidemiological for use in the Dutch cancer registry for
research. Int $\mathcal{F}$ Epidemiol 1990;19:553-8.

20 Van den Brandt PA, Van 't Veer P, Goldbohm RA, Dorant E, Volovics A, Hermus RJJ, Sturmans F. A prospective E, Volovics A, Hermus RJj, Sturmans F. A prospective cohort study on dietary fat and the risk of post

21 Liberatos P, Link BG, Kelsey JL. The measurement of social class in epidemiology. Epidemiol Rev 1988;10:87-121.

22 Centraal Bureau voor de Statistiek. Berepenclassificatie 1984 Lijst van benamingen per beroepencode. Voorburg: CBS 1985

23 Erikson R, Goldthorpe JH, Portocarero L. Intergenerationa class mobility in three western countries: England, France and Sweden. British fournal of Sociology 1979;30:415-41.

24 Van Berkel-van Schaik AB, Tax B. Naar een standaardoperationalisatie van sociaal-economische status voor epidemiologisch en sociaal-medisch onderzoek. Sociaal-economische gezondheidsverschillen no 6. Den Haag: DOP, 1990.

25 Ganzeboom H, Luykx R, Dessens J, De Graaf P, De Graa ND, Jansen W, Ultee W. Intergenerationele klassenmobiliteit in Nederland tussen 1970 en 1985. Mens en Maatschappij 1987;62:17-43.

26 Goldbohm RA, Van den Brandt PA, Brants HAM, Van 't Veer P, Al M, Sturmans F, Hermus RJJ. Validation of a dietary questionnaire used in a large-scale prospective cohort study on diet and cancer. Eur $\mathcal{F}$ Clin Nutr 1994 48:253-65.

27 Stichting NEVO. NEVO-tabel; Nederlands voedingsstoffenbestand 1986-1987. The Hague: Voorlichtingsbureau voor de voeding. 1986

28 Self SG, Prentice RL. Asymptotic distribution theory and efficiency results for case-cohort studies. Ann Stat 1988 16:64-81.

29 Baker RJ. Glim 3.77. Reference Manual. Oxford: Numerical Algorithms Group, 1985.

30 Zurayk $\mathrm{H}$, Halabi S, Deeb $\mathrm{M}$. Measures of social class based on education for use in health studies in developing countries. $\mathcal{F}$ Epidemiol Community Health 1987;41:173-9.

31 Thijssen LJM. Sociale stratificatie onder ouderen. Soc Cult Kwartber 1986;8(2):10-27.

32 Wetenschappelijke Raad voor het Regeringsbeleid. Over sociale ongelijkheid. Rapporten aan de regering no 16. Den Haag: Staatsuitgeverii, 1977.

33 Winkleby MA, Jatulis DE, Frank E, Fortmann SP. Socioeconomic status and health: How education, income and occupation contribute to risk factors for cardiovascular disease. Am $\mathcal{F}$ Publ Health 1992;82:816-20.

34 Hein HO, Suadicani P, Gyntelberg F. Lung cancer risk and social class. The Copenhagen male study-17-year follow up. Dan Med Bull 1992;39:173-6.

35 Fox AJ, Adelstein AM. Occupational mortality: work or way of life? 7 Epidemiol Community Health 1978:32:73-8.

36 Pastorino U, Berrino F, Gervasio A, Presenti V, Riboli E, Crosignani P. Proportion of lung cancers due to occupational exposure. Int J Cancer 1984;33:231-7.

37 Jöckel KH, Ahrens W, Wichmann HE et al. Occupationa and environmental hazards associated with lung cancer. and environmental hazards asso

38 Notani PN, Shah P, Jayant K, Balakrishnan V. Occupation and cancers of the lung and bladder: A case-control study in Bombay. Int $\mathcal{F}$ Epidemiol 1993;22:185-91. 